\title{
Income management and Indigenous peoples: nudged into a Stronger Future?
}

Shelley Bielefeld*

School of Law, University of Western Sydney, Australia

\begin{abstract}
Australian policy has been motivated by paternalism towards Indigenous peoples for the better part of Australia's colonial history. Contemporary forms of income management that disproportionately affect Indigenous peoples extend a paternalistic approach. The paternalism embedded within the income management discourse draws heavily upon the framework of 'new paternalism', which increases government supervision of those who receive welfare payments. However, in recent years, another form of paternalism has also been growing in popularity with Western governments - 'nudge paternalism' - which may have future implications for policymaking in the welfare context in Australia. This article comprises three parts. The first part explores specific problems that can arise with paternalistic policy-making directed towards Indigenous peoples, including nudge paternalism. The second part considers how income management departs from the principles of nudge paternalism, and the impact that income management has on Indigenous peoples. The final part explores some alternative suggestions for policy initiatives to address disadvantage experienced by Indigenous welfare recipients, particularly those living in the Northern Territory.
\end{abstract}

\section{Introduction}

Australian policy has been motivated by paternalism towards Indigenous peoples for the better part of Australia's colonial history. Contemporary forms of income management that disproportionately affect Indigenous peoples extend a paternalistic approach. The paternalism embedded within the income management discourse draws heavily upon the framework of 'new paternalism', which increases government supervision of those who receive welfare payments. ${ }^{1}$ Income management can be seen as a form of hard paternalism, because it restricts the liberty of those subject to it and the government claims to do so out of benevolence towards welfare recipients. ${ }^{2}$ However, in recent years, another form of paternalism has grown in popularity with Western governments - 'nudge paternalism' - developed by Richard Thaler and Cass Sunstein. ${ }^{3}$ Thaler and Sunstein have influenced policy development in the United States

*Email: s.bielefeld@uws.edu.au

${ }^{1}$ Mead (1997), p 1.

${ }^{2}$ Commonwealth of Australia (2007) Parliamentary Debates, House of Representatives, 7 August, 6 (Malcolm Brough); Commonwealth of Australia (2009) Parliamentary Debates, House of Representatives, 25 November, 12786 (Jennifer Macklin); Commonwealth of Australia (2011) Parliamentary Debates, House of Representatives, 13540 (Jennifer Macklin); Dworkin (2013), p 30.

${ }^{3}$ Thaler and Sunstein (2009); Sunstein (2013), pp 2, 4, 13-14. 
and the United Kingdom. President Obama appointed Sunstein as chief regulator in the White House Office of Information and Regulatory Affairs in the United States, and Thaler has been an adviser to Prime Minister David Cameron in the United Kingdom where there is now a 'Behavioural Insights Team, located in his Cabinet Office [...] informally called the "Nudge Unit". 4 This article comprises three parts. The first part explores specific problems that can arise with paternalistic policy-making directed towards Indigenous peoples, including nudge paternalism. The second part considers how income management departs from the principles of nudge paternalism, and the impact that income management has on Indigenous peoples. The final part explores some alternative suggestions for policy initiatives to address disadvantage experienced by Indigenous welfare recipients, particularly those living in the Northern Territory.

In recent decades, paternalistic governance has become more prevalent in the context of social welfare law and policy, both in Australia and in other Western nations. ${ }^{5}$ There are various forms of paternalism; however, common to "paternalistic approaches' is a belief that people do not make welfare enhancing choices and, therefore, the government needs 'to influence or alter people's choices for their own good'. ${ }^{6}$ Sunstein claims that nudge paternalism is founded upon 'behavioural economics' which studies 'how people actually act, rather than how standard economic theory supposes that they act'. ${ }^{7} \mathrm{He}$ explains that:

Nudges consist of approaches that do not force anyone to do anything and that maintain freedom of choice, but that have the potential to make people healthier, wealthier, and happier. [...] Those who favour nudges recognize the importance of freedom of choice. They respect free markets and private liberty. They allow people to go their own way. At the same time, they emphasize that people may err and that $[\ldots]$ most of us could use a little help. ${ }^{8}$

Nudge paternalism involves structuring the choices that people can make in an attempt to steer them towards making the 'right' choices. ${ }^{9}$ Thaler and Sunstein describe this as 'libertarian paternalism'. ${ }^{10}$ Unlike some forms of paternalism, advocates of nudge paternalism claim that it is a 'soft' type of paternalism, because it does 'not impose material costs on people's choices'. ${ }^{11}$ By contrast, they say 'hard' paternalism does 'impose material costs on people's choices'. ${ }^{12}$ Thaler and Sunstein see some type of paternalistic intervention as inevitable. ${ }^{13}$ They consider soft paternalism

\footnotetext{
${ }^{4}$ Sunstein (2013), pp 1-2, 4, 13; Standing (2014a), p 97.

${ }^{5}$ Thomas and Buckmaster (2010), p 1.

${ }^{6}$ Sunstein (2013), pp 191-192.

${ }^{7}$ Sunstein (2013), pp 2, 5.

${ }^{8}$ Sunstein (2013), p 9.

${ }^{9}$ Thaler and Sunstein (2009), pp 3-4, 6; Standing (2014a), pp 96-97.

${ }^{10}$ Thaler and Sunstein (2009), p 5.

${ }^{11}$ Sunstein (2013), pp 193-194, cf Scoccia (2013), pp 74, 80.

${ }^{12}$ Sunstein (2013), p 193.

${ }^{13}$ Sunstein and Thaler (2003), pp 1159, 1166, 1177.
} 
as a preferable form of paternalism, and therefore promote numerous 'nudges' in public policy. In this way, nudge paternalists have diverted the policy debate away from considering whether paternalism is desirable, and towards a more limited choice between hard paternalism and soft paternalism. This limited debate is likely to be particularly unhelpful in the context of Indigenous policy-making, as paternalism has a long history of not working effectively for Indigenous peoples. Paternalism has an infantilising tendency; it can embed 'cultural imperialism', and can also operate as an expression of superiority by the government towards those whose behaviour they seek to alter. ${ }^{14}$ These features of paternalism are often offensive to Indigenous peoples and run counter to Indigenous peoples' desire for self-determination. ${ }^{15}$

In Australia, the impetus towards government paternalism has a particularly significant impact for Indigenous peoples, as seen in recent developments in income management. ${ }^{16}$ Under income management, 50 per cent or more of a welfare recipient's income is used to purchase government approved 'priority needs' using a government issued BasicsCard with a PIN number. ${ }^{17}$ Income management also restricts welfare recipients from using their BasicsCard to purchase alcohol, tobacco, pornographic material ${ }^{18}$ and gambling services. ${ }^{19}$ The Australian government is the only country to have adopted 'this particular system for controlling how welfare recipients spend their payments'. ${ }^{20}$

In its contemporary manifestation, compulsory income management was commenced in 2007, allegedly as an interim emergency measure under the Northern Territory Emergency Response (the Intervention). ${ }^{21}$ The Little Children Are Sacred report, ${ }^{22}$ which had identified problems of sexual abuse of Aboriginal children in some remote Aboriginal communities, was used by the government to introduce a range of sweeping legislative changes in the Northern Territory, of which income management was one. ${ }^{23}$ The government claimed that compulsory income management would ensure that Aboriginal welfare recipients spent their income in a way that would benefit Aboriginal children and prevent them from harm. ${ }^{24}$ The government maintained that these welfare reforms were necessary because welfare payments for Aboriginal peoples

\footnotetext{
${ }^{14}$ Young (1990), p 59; Coons and Weber (2013), pp 12-13.

${ }^{15}$ Behrendt (2003), pp 90, 93, 98-99; Moreton-Robinson (2005), pp 61, 63, 65; Churchill (2011), pp 540, 543; Venne (2011), pp 557, 568, 573; Watson (2011), p 508.

${ }^{16}$ Bielefeld (2012), pp 522-562; Bray et al (2012), p 254.

${ }^{17}$ 'Priority needs' are legislatively defined, Social Security (Administration) Act 1999 (Cth) s $123 \mathrm{TH}(1)$.

${ }^{18}$ Social Security (Administration) Act 1999 (Cth) s 123TI(1).

${ }^{19}$ Social Security (Administration) Act 1999 (Cth) s 123TI(2).

${ }^{20}$ Thomas and Buckmaster (2010), p 25.

${ }^{21}$ Social Security and Other Legislation Amendment (Welfare Payment Reform) Act 2007 (Cth).

${ }^{22}$ Northern Territory Government (2007).

${ }^{23}$ Commonwealth of Australia (2007) Parliamentary Debates, House of Representatives, 6 (Malcolm Brough).

${ }^{24}$ Commonwealth of Australia (2007) Parliamentary Debates, House of Representatives, 2-4, 6 (Malcolm Brough).
} 
had led to 'an intergenerational cycle of dependency' and 'become a trap instead of a pathway'. ${ }^{25}$ It was said that the reforms were needed to:

$[\mathrm{H}]$ elp $[\ldots]$ stem the flow of cash going towards substance abuse and gambling and ensure that funds meant to be for children's welfare are used for that purpose [...] to minimise the practice known as 'humbugging' in the Northern Territory, where people are intimidated into handing over their money to others for inappropriate needs, often for alcohol, drugs and gambling. ${ }^{26}$

Compulsory income management was initially restricted to Aboriginal welfare recipients in Northern Territory prescribed communities. The government claimed that these communities needed to be 'stabilised and normalised' ${ }^{27}$ However, there has now been a broader extension of the income management laws and policies, both in $2010^{28}$ and in $2012 .^{29}$ This shows the potential for paternalistic interim measures to become the new 'normal'.

The 2010 amendments were introduced after there had been substantial criticism about human rights violations embedded within the 2007 laws. ${ }^{30}$ The 2007 laws had expressly targeted Aboriginal peoples in receipt of welfare payments in Northern Territory prescribed communities, regardless of their actual capacity to manage their finances responsibly, or whether they had responsibility to care for children, or whether they had a history of child abuse or neglect. ${ }^{31}$ The 2007 laws excluded the operation of the Racial Discrimination Act 1975 (Cth) (RDA) prohibiting racial discrimination. ${ }^{32}$ This meant that Indigenous welfare recipients who were experiencing racial discrimination through the income management scheme had no legal remedy within Australia to redress this injustice. Consequently, the government claimed to reinstate the RDA with the 2010 measures. ${ }^{33}$ However, the income management categories in the 2010 laws still disproportionately apply to Indigenous peoples. ${ }^{34}$

The 2010 laws created a range of income management categories. Thus, compulsory income management continues in the Northern Territory for those defined as 'disengaged youth', 'long term', or 'vulnerable' welfare recipients, and if

\footnotetext{
${ }^{25}$ Commonwealth of Australia (2007) Parliamentary Debates, House of Representatives, 6 (Malcolm Brough).

${ }^{26}$ Commonwealth of Australia (2007) Parliamentary Debates, House of Representatives, 6 (Malcolm Brough).

${ }^{27}$ Commonwealth of Australia (2007) Parliamentary Debates, House of Representatives, 7 (Malcolm Brough).

${ }^{28}$ Social Security and Other Legislation Amendment (Welfare Reform and Reinstatement of Racial Discrimination Act) Act 2010 (Cth).

${ }^{29}$ Social Security Legislation Amendment Act 2012 (Cth) Sch 1.

${ }^{30}$ Letter from the United Nations to the Australian Government, http://www2.ohchr.org/ english/bodies/cerd/docs/early_warning/Australia28092009.pdf, 28 September 2009.

${ }^{31}$ Webb (2008), p 18; Shaw and Martin (2009).

${ }^{32}$ Social Security and Other Legislation Amendment (Welfare Payment Reform) Act 2007 (Cth) ss 4(3), 6(3).

${ }^{33}$ Commonwealth of Australia (2009) Parliamentary Debates, House of Representatives, 12787 (Jennifer Macklin); Social Security and Other Legislation Amendment (Welfare Reform and Reinstatement of Racial Discrimination Act) Act 2010 (Cth).

${ }^{34}$ Bray et al (2012), p 254.
} 
there is a child protection issue. ${ }^{35}$ Another 2010 category is 'voluntary' income management, which can involve less coercion than the other forms, so long as welfare recipients genuinely wish to choose this option, something questioned by numerous stakeholders. ${ }^{36}$

The 2012 extensions to income management were implemented as part of the Stronger Futures legislative package. ${ }^{37}$ As the name of this law and policy package indicates, the stated intention of the government is that Indigenous peoples will experience a better future as a consequence of these comprehensive new laws. ${ }^{38}$ Thus, Minister Macklin stated that these laws were enacted to create a 'stronger future [...] for Aboriginal people'. ${ }^{39}$ However, these extensions mean that the forms of paternalistic intervention seen in income management will now operate indefinitely. What started as an 'emergency' measure has now been normalised as a routine system of surveillance for many welfare recipients. Although these income management laws and policies now also apply to non-Indigenous as well as Indigenous Australians, they still 'overwhelmingly' affect Aboriginal peoples and 'Aboriginal communities'. ${ }^{40}$ Yet the government claims that the new income management measures are now 'non-discriminatory'. ${ }^{41}$

The government maintains that the income management laws and policies are intended to be helpful for welfare recipients. Thus, the Explanatory Memorandum for the Social Security Legislation Amendment Act 2012 (Cth), which implements the 2012 extensions to the income management scheme, states:

The income management regime [...] operates as a tool to support vulnerable individuals and families. It provides a tool to stabilise people's circumstances by limiting expenditure of income support payments on excluded items, including alcohol, tobacco, pornography, gambling goods and activities. ${ }^{42}$

However, the income management laws and policies have a significant impact upon Indigenous peoples' rights to autonomy, self-determination and wellbeing. This article

\footnotetext{
${ }^{35}$ Social Security and Other Legislation Amendment (Welfare Reform and Reinstatement of Racial Discrimination Act) Act 2010 (Cth) s 25. The categories of 'vulnerable welfare payment recipients', 'disengaged youth', and 'long term welfare payment recipients' are defined in Social Security and Other Legislation Amendment (Welfare Reform and Reinstatement of Racial Discrimination Act) Act 2010 (Cth) s 36. This has resulted in amendments to the Social Security (Administration) Act 1999 (Cth), for example, pursuant to s $123 \mathrm{UC}$ a person will fall under the compulsory income management regime if there is a child protection issue.

${ }^{36}$ Australian Law Reform Commission (2011), p 272.

${ }^{37}$ Stronger Futures in the Northern Territory Act 2012 (Cth); Stronger Futures in the Northern Territory (Consequential and Transitional Provisions) Act 2012 (Cth); Social Security Legislation Amendment Act 2012 (Cth).

${ }^{38}$ Commonwealth of Australia (2011) Parliamentary Debates, House of Representatives, 13539 (Jennifer Macklin).

${ }^{39}$ Commonwealth of Australia (2011) Parliamentary Debates, House of Representatives, 13539 (Jennifer Macklin).

${ }^{40}$ Bray et al (2012), p 254; Parliamentary Joint Committee on Human Rights (2013), pp 51-52.

${ }^{41}$ Commonwealth of Australia (2011) Parliamentary Debates, House of Representatives, 12787, 13543 (Jennifer Macklin).

${ }^{42}$ Explanatory Memorandum to the Social Security Legislation Amendment Bill 2011, p 2.
} 
contends that the need to improve the socioeconomic circumstances of Indigenous peoples is incontrovertible, but the process of redressing disadvantage must be culturally appropriate, effective and empowering, rather than disempowering. Moreover, the process of addressing disadvantage must not continue colonisation under another name, as the compulsory income management scheme does, by reproducing 'racially shaped spaces [...] possibilities [...] and exclusions' ${ }^{43}$ The process of addressing disadvantage needs to respect both the individual and collective human rights of Indigenous peoples and their collective right to self-determination. ${ }^{44}$

\section{Part I: Nudge paternalism: a new way forward or a limiting framework?}

This part of the article will consider several problems with paternalistic policymaking directed towards Indigenous peoples, and various aspects of the theory of nudge paternalism. This is worthwhile reflecting upon due to global policy developments where nudge paternalism is growing in prominence. This may cause the Australian government to contemplate a shift from new paternalism towards nudge paternalism at some future point, given that Australia has a tendency to be influenced by policy developments in the United States and the United Kingdom. ${ }^{45}$ Although some see nudge paternalism as a softer option in terms of paternalistic approaches, there would still be philosophical incongruities between nudge paternalism and the aspirations, values and ethics of many Indigenous peoples. This part will consider some problematic assumptions underpinning nudge paternalism and how it could potentially nudge Indigenous peoples towards majoritarian preferences without respecting difference in terms of Indigenous cultural values.

\section{Choice architecture: a framework for a 'better' life?}

Thaler and Sunstein claim that a nudge paternalist is simply a 'choice architect' with 'responsibility for organising the context in which people make decisions'. ${ }^{46}$ They maintain that the role of a nudge paternalist is to influence what choices people make ${ }^{47}$ stating 'choice architects are [...] self-consciously attempting to move people in directions that will make their lives better. They nudge'. ${ }^{48}$ This sounds well

\footnotetext{
${ }^{43}$ Goldberg (2002), p 104.

${ }^{44}$ United Nations Declaration on the Rights of Indigenous Peoples 2007, Art 3; Watson (1997), p 55; Mansell (2007), p 80. The right of self-determination for Australia's First Peoples is discussed in Part III of this article. The author notes that some consider that the right to selfdetermination for Indigenous peoples should be extended to individuals as well as being a collective right, see for example the editorial note by Jumbunna Indigenous House of Learning preceding Altman (2013), $\mathrm{p}$ iv. However, this position, whilst having much to commend it in terms of combating unwanted paternalism, is yet to be broadly adopted under international law.

${ }^{45}$ Australia's adoption of new paternalism in the area of welfare policy supports this proposition about overseas influence. Mead (1997), p 1; Thomas and Buckmaster (2010), p 1.

${ }^{46}$ Thaler and Sunstein (2009), p 3.

${ }^{47}$ Thaler and Sunstein (2009), p 4.

${ }^{48}$ Thaler and Sunstein (2009), p 6. Guy Standing (2014a, pp 96-97, 226-227, 242) critiques the concept of 'choice architecture' on a number of bases, including that Thaler and Sunstein 'used Benthamite language, without attribution' in regards to 'Bentham's panopticon, an all seeing surveillance device initially designed for prisons that aimed to identify for punishment those "not making the right choice".
} 
intentioned. However, the problem lies in the value judgement that attaches to what is considered to be 'better' and who it is that ultimately gets to determine that important issue. Although Thaler and Sunstein may consider that the criteria about what constitutes a better life is to be determined by the individual concerned, ${ }^{49}$ nudge paternalism, like any other form of paternalism, can ultimately be used by the government to attempt to justify a broad range of law and policy objectives that raise ethical concerns. ${ }^{50}$ Nudge paternalism, like so many of the forms of paternalism that have preceded it, can overlook the means used to try to justify or facilitate particular ends, yet the means used are equally important in terms of genuinely promoting superior outcomes. ${ }^{51}$ For example, it seems somewhat obvious that Indigenous citizens cannot experience 'better' lives when the means the government chooses to use override their individual and collective human rights and infringe their collective right to self-determination, ${ }^{52}$ as occurs with the income management scheme. In June 2013 the Parliamentary Joint Committee on Human Rights explored the relationship between income management and international human rights laws that Australia has ratified. They concluded that although 'the measures have been extended to communities that are not predominantly Aboriginal' they 'still apply overwhelmingly to [...] Aboriginal communities' and therefore 'fall within the definition of racial discrimination'. ${ }^{53}$ The committee also found the income management scheme breached other human rights, including 'the right to social security and the right not to have one's privacy and family life interfered with unlawfully or arbitrarily'. ${ }^{54}$ It seems doubtful that laws and policies which violate human rights will produce the beneficial outcomes the government claims to want to achieve.

Indeed, the income management scheme was predicted to cause significant harm to Indigenous peoples by the Australian Indigenous Doctors' Association (AIDA) in its 2010 report, which stated that:

[T]he compulsory quarantining of income of Aboriginal welfare recipients will have significant negative effects on the mental health and social functioning of individuals and communities - including children. These are serious health consequences [...] and will have serious, harmful impacts on the physical health of young people and adults across the life span. ${ }^{55}$

\footnotetext{
${ }^{49}$ Thaler and Sunstein (2009), p 5.

${ }^{50}$ Including threats to due process, Standing (2014a), pp 226-227.

${ }^{51}$ Mansell (2007), pp 73, 81.

${ }^{52}$ United Nations Declaration on the Rights of Indigenous Peoples Article 3; Watson (1997), p 55; Mansell (2007), p 80. The right of self-determination for Australia's First Peoples is discussed in Part III of this article.

${ }^{53}$ Parliamentary Joint Committee on Human Rights (2013), pp 51-52, under the International Convention on the Elimination of All Forms of Racial Discrimination 1969, Art 1.

${ }^{54}$ Parliamentary Joint Committee on Human Rights (2013), p 60, under the International Covenant on Civil and Political Rights 1976, Art 17(1) and the International Covenant on Economic, Social and Cultural Rights 1976, Art 9.

${ }^{55}$ Australian Indigenous Doctors' Association and Centre for Health Equity Training (2010), p 24.
} 
In terms of the negative impact of compulsory income management on the 'psychological health' of Aboriginal welfare recipients, AIDA highlighted that the scheme led to side effects of '[a]nger', '[c]umulative trauma - shame, [and] discrimination', '[s]tress associated with costs and use of [the] "basics card", and '[t]rans-generational trauma' caused by 'children seeing parents' control and capacity undermined'. ${ }^{56}$ In terms of the negative impact of compulsory income management on 'social health and wellbeing', AIDA noted both the '[i]ncreased costs for transport and food' and the '[d]enial of rights of Aboriginal adults to solve their own problems'. ${ }^{57}$ However, instead of listening to the expert opinions of Aboriginal medical professionals, the government maintained and expanded compulsory income management, which disproportionately applies to Indigenous peoples - over 90 per cent of income managed welfare recipients in the Northern Territory are Indigenous. ${ }^{58}$

The government has not attended to the negative impacts of intrusive paternalistic surveillance on Indigenous peoples. Michele Harris argues the government's paternalistic intervention approach has not facilitated 'improvements' because 'for health to improve, people must have increased control over their life' ${ }^{59}$ Harris claims the government's approach has been directed towards 'confusing, disorienting and undermining Aboriginal self-worth', and has resulted in 'disempowerment', 'incredible harm' and 'trauma' for Aboriginal people affected by the Intervention. ${ }^{60}$ This mirrors the position of Northern Territory elders, Rosalie Kunoth-Monks and Djiniyini Gondarra, who are part of the United First Peoples Law Men and Women. ${ }^{61}$ These are important ethical issues. Unfortunately, the pursuit of a 'better' life facilitated by paternalists can lead to the unintended outcomes that Harris describes. Like other forms of colonial paternalism, nudge paternalism can be imbued with the 'paternalistic arrogance of imperialism'. ${ }^{62}$ Indigenous peoples in Australia have a long history with government paternalism, with lawmakers and bureaucrats assuming they know best what will create a 'better' life for Indigenous peoples. This history will shape how paternalistic policies are perceived and experienced by Indigenous peoples.

Australia's history is littered with examples of paternalistic laws and policies that have had a detrimental impact upon Indigenous peoples. The assimilation laws and policies that were implemented allegedly for the benefit of Indigenous peoples are a clear example. Each Australian jurisdiction adopted policies of assimilation. ${ }^{63} \mathrm{Such}$ policies were laden with assumptions about the worthlessness of Aboriginal culture and the inferiority of Aboriginal peoples. They facilitated the forced removal of

\footnotetext{
${ }^{56}$ Australian Indigenous Doctors' Association and Centre for Health Equity Training (2010), p 25.

${ }^{57}$ Australian Indigenous Doctors' Association and Centre for Health Equity Training (2010), p 25.

${ }^{58}$ Bray et al (2012), pp 6, 192.

${ }^{59}$ Harris (2013a), p 4.

${ }^{60}$ Harris (2013a), p 33; Harris (2013b), p 5.

${ }^{61}$ Rollback the Intervention (2012).

${ }^{62}$ Said (1994), p xviii.

${ }^{63}$ Human Rights and Equal Opportunity Commission (1997), p 32.
} 
Aboriginal children, the slave labour of many Aboriginal peoples, and arranged marriages to 'breed out the colour'. ${ }^{64}$ This history can lead numerous Aboriginal peoples to see paternalism in all its forms as ongoing 'colonial violence', ${ }^{65}$ regardless of the proclaimed good intentions of its inventors and administrators. For example, Irene Watson writes of 'the inherent violence of the Aborigines Acts and all the violence that racist paternalistic legislation justified' ${ }^{66}$ The government has routinely constructed 'Indigenous subjects as requiring the paternal willpower of the state for salvation'. ${ }^{67}$ It should not be surprising, therefore, that numerous Indigenous peoples are now reluctant to place their trust in government law and policy-makers who claim that new forms of paternalism will lead to 'better' outcomes. There is too long a history of colonial authorities disregarding the best interests of Indigenous peoples, as defined by Indigenous peoples, in order to impose paternalistic 'solutions' ${ }^{68}$

\section{Libertarian paternalism: promoting 'free' choice, 'better' choice or 'right' choice?}

Thaler and Sunstein have coined the phrase 'libertarian paternalism' as a way of describing what nudge paternalism aims to achieve. ${ }^{69}$ They explain:

[L]ibertarian paternalists urge that people should be 'free to choose.' We strive to design policies that maintain or increase freedom of choice. When we use the word libertarian to modify the word paternalism, we simply mean liberty-preserving. [...] Libertarian paternalists want to make it easy for people to go their own way; they do not want to burden those who want to exercise their freedom.

The paternalistic aspect lies in the claim that it is legitimate for choice architects to try to influence people's behaviour in order to make their lives longer, healthier, and better. [...] we argue for self-conscious efforts by institutions in the private sector and also by government, to steer people's choices in directions that will improve their lives. [...] a policy is 'paternalistic' if it tries to influence choices in a way that will make choosers better off, as judged by themselves. [...] [However] in many cases, individuals make pretty bad decisions - decisions they would not have made if they had paid full attention and possessed complete information, unlimited cognitive abilities, and complete selfcontrol. $^{70}$

This extract is interesting in terms of the underlying assumptions it makes in a range of areas. Three key points need to be made about this extract.

Nudge paternalism limits choices to those able to be conceptualised or willingly prioritised by policy-makers or industry magnates

First, although nudge paternalists claim not to want to burden freedom and to make it easy for people to choose according to their own preferences, by limiting the range

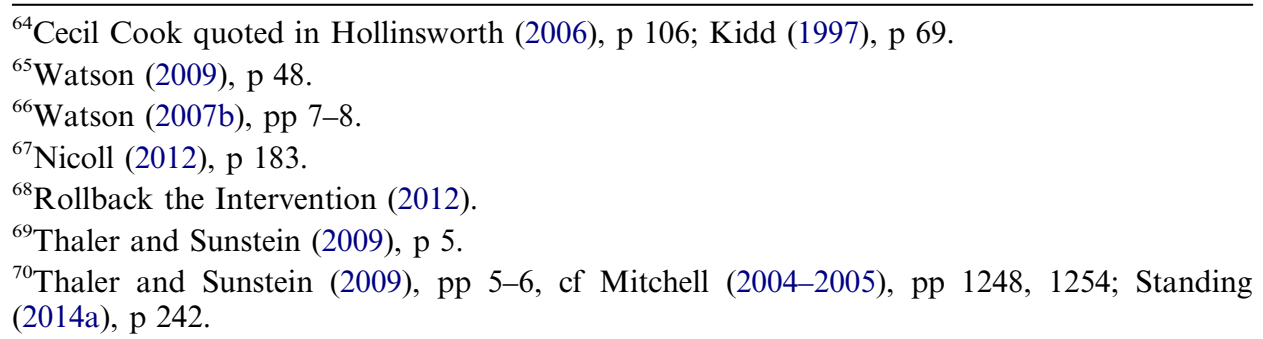


of options to those able to be conceptualised or willingly prioritised by policy-makers or industry magnates at a particular point in time, they are in fact limiting choice rather than enhancing it. This framework does not allow for the possibility that some people may well have preferences outside of those that are readily identified or prioritised by policy-makers or industry magnates. This is relevant in the context of income management and Indigenous peoples in regards to income sharing and reciprocity. Sharing income and resources are cultural values of significance to many Indigenous peoples, ${ }^{71}$ and yet the framework constructed by the inventors of income management can lead to Indigenous peoples being categorised as 'vulnerable' and subject to compulsory income management if they share their income. This is because such income sharing may be regarded negatively as a form of 'financial exploitation, ${ }^{72}$ by those who assess whether or not a welfare recipient is affected by 'vulnerability'. In June 2012, the Commonwealth Ombudsman's Office noted that Centrelink officers responsible for making this kind of determination tend to have a negative perception of income sharing. Thus they stated:

In the decisions we reviewed, we noted a tendency to treat advice that a [welfare recipient] shared income with others as evidence that the [person] was experiencing financial exploitation. The Principles say that financial exploitation has occurred when someone has acquired, attempted to acquire or is acquiring the use of, or an interest in, some or all of another person's financial resources. This acquisition must involve undue pressure, harassment, violence, abuse, deception, duress, fraud or exploitation. Therefore, if sharing is reciprocal, voluntary and equitable, it should not be labelled as financial exploitation. ${ }^{73}$

However, this approach, which involves a more conceptually nuanced evaluation of income sharing, was not adopted by many Centrelink officers. This had the effect of leaving Indigenous welfare recipients subject to Eurocentric values and, significantly, subject to compulsory income management.

Value judgements can play a significant role in nudge paternalism and these value judgements can reproduce power imbalances

Second, although Thaler and Sunstein say the aim of nudge paternalism is to result in people living 'longer, healthier, and better' lives, they do not acknowledge the complexity or, in some instances, the possible incompatibility between these objectives. Are people living better lives if they are living longer? Is longevity the only valid benchmark by which a better life can be determined? What about happiness? ${ }^{74}$ Much

\footnotetext{
${ }^{71}$ Altman (2011), pp 191, 193-194.

${ }^{72}$ 'Financial exploitation' is one of the criteria used to determine whether someone is affected by vulnerability under the Social Security (Administration) (Vulnerable Welfare Payment Recipient) Principles 2013 and the Social Security (Administration) (Exempt Welfare Payment Recipients - Persons with Dependent Children) (Indications of Financial Vulnerability) Principles 2010 made by the Minister in accordance with Social Security (Administration) Act 1999 (Cth) s 123UGA(2).

${ }^{73}$ Commonwealth Ombudsman (2012), p 30. The Principles referred to are the Social Security (Administration) (Vulnerable Welfare Payment Recipient) Principles 2010 made by the Minister in accordance with Social Security (Administration) Act 1999 (Cth) s 123UGA(2).

${ }^{74}$ Michele Harris (2013a), p 4.
} 
will depend upon the values possessed and the choices made by those engaged in the definition process. In ascertaining whether a better life is actually being created for Indigenous peoples, the government tends to measure statistical data containing criteria of the government's own construction, ${ }^{75}$ but in this process there can be a Eurocentric bias which can be at odds with values held by many Indigenous peoples. A merited criticism that can be raised in relation to nudge paternalism is that "choice architects in all walks of life have incentives to nudge people in directions that benefit the architects (or their employers) rather than the users' ${ }^{76}$ This can have the consequence of reproducing colonial imbalances of power and entrenching, rather than redressing, disadvantage experienced by Indigenous peoples. ${ }^{77}$ There can be a vested interest in assigning particular values to certain outcomes and in seeking to restructure human behaviour in the manner advocated by nudge paternalists. ${ }^{78}$ Yet Thaler and Sunstein appear to be blind to the value judgements that can be used to determine what constitutes a 'longer, healthier, and better' life. Such matters are likely to be perceived differently by people depending upon a range of variable factors, including culture. As Richard Bellamy points out, 'there is no science of best destinations for all people apart from what they themselves see as most suitable given what they seek out of life'. ${ }^{79}$

\section{Nudge paternalism adopts simplistic conceptions of right and wrong}

Third, Thaler and Sunstein claim nudge paternalism can be justified because of the propensity that people have to make bad choices. They claim nudge paternalism is necessary because '[h] umans make mistakes' ${ }^{80}$ However, this seems to be a poor justification for the type of paternalism they advocate. Thaler and Sunstein appear to adhere to simplistic conceptions of right and wrong in their theoretical musings. They say 'sensible choice architecture guides people in the right directions'. ${ }^{81}$ However, one has to ask - right according to whom? Right according to the neoliberal ideology of the colonial state? ${ }^{82}$ Or right according to the culture, ethics and values of Indigenous peoples? ${ }^{83}$ The simplistic assumptions of Thaler and Sunstein appear to be premised on 'value monism', which is 'the idea that the good is singular and there is one kind of life that it is best for human beings to live' ${ }^{84}$ However, in the context of law and policy affecting Indigenous peoples, there is always a diversity of opinion; and to call the state position 'right' because they have a position of power is simply another means of continuing colonisation, regardless of

\footnotetext{
${ }^{75}$ Altman and Russell (2012), p 17.

${ }^{76}$ Thaler and Sunstein (2009), p 238. See also Standing (2014a), p 242.

${ }^{77}$ Newcomb (2011), pp 581, 584, 599.

${ }^{78}$ Sunstein (2013, p 196) does acknowledge, to some extent, the potential for there to be a problem of bias among public officials in his later work, although he suggests that concern about the executive government being influenced by powerful interest groups is overstated.

${ }^{79}$ Bellamy (2008), p 106.

${ }^{80}$ Thaler and Sunstein (2009), p 96.

${ }^{81}$ Thaler and Sunstein (2009), p 163.

${ }^{82}$ Altman (2012a), p xvi; Altman (2012b), p 18.

${ }^{83}$ Arabena (2006), p 38; Altman and Hinkson (2010), p 189.

${ }^{84}$ Mackenzie (2008), p 528.
} 
whatever label the government wants to attach to their law and policy, be it Stronger Futures or some other equally Orwellian substitute. ${ }^{85}$

Thaler and Sunstein claim 'human fallibility' may benefit from nudge paternalism since people:

[C]annot afford to think deeply about every choice they have to make. [...] Because they are busy and have limited attention, they accept questions as posed rather than trying to determine whether their answers would vary under alternative formulations. The bottom line $[\ldots]$ is that people are $[\ldots]$ nudge-able. ${ }^{86}$

They imply that people are too busy or intellectually disengaged to think for themselves - so it is then legitimate to let others do it for them. This has the effect of infantilising adults, depriving citizens of autonomy and agency. However, autonomy is an essential component of citizenship. As Elizabeth Ben-Ishai argues, 'citizenship is in many ways the political realization of autonomy'. ${ }^{87}$ Catriona Mackenzie also places great significance on autonomy, and explains that 'promotion of autonomy is a matter of social justice' and without the government creating autonomy fostering policies 'the social conditions necessary for genuine respect' are unlikely to eventuate. ${ }^{88}$ These issues are particularly important for Indigenous peoples who have been treated as child-like inferiors throughout so much of Australia's racist colonial history and denied the rights of citizens. ${ }^{89}$

Another significant point is that paternalists can possess the same character or cognitive flaws they claim to need to redress in others. ${ }^{90}$ This means that any system designed by nudge paternalists to facilitate choices can be flawed, and therefore not necessarily produce superior choices than those people would otherwise have made without the paternalistic nudge. Rather, in the context of Indigenous policy-making, paternalists can help perpetuate a fantasy of colonial competence to regulate the so called 'unsophisticated' ways of those deemed to be 'primitive' people according to a Eurocentric framework. ${ }^{91}$ In this sense it shares a commonality with John Stuart Mill's claim that 'despotism' is legitimate when seeking to regulate the lives of 'barbarians'. ${ }^{92}$ Irene Watson has argued that 'the racist discourse of the primitive barbarian' 93 has been central to the government's justification of the Northern Territory Intervention, with all its varied forms of paternalistic control, including

\footnotetext{
${ }^{85}$ Manderson (2012), p 412; Bielefeld (2014), p 15.

${ }^{86}$ Thaler and Sunstein (2009), p 40.

${ }^{87}$ Ben-Ishai (2012), p 2.

${ }^{88}$ Mackenzie (2008), p 530.

${ }^{89}$ Mercer (2003), pp 422-425, 429, 431, 434; Hollinsworth (2006), p 100; Dodson and Cronin (2011), p 195; Banivanua Mar (2012), pp 189-191; Howard-Wagner (2012), pp 226, 228; Anthony (2013), pp 45, 46, 48.

${ }^{90}$ Thomas and Buckmaster (2010), p 17. Sunstein (2013, p 71) later acknowledged that 'public officials are human and they can err as well'. However, it is possible that governments may choose not to focus on this later theoretical modification to nudge paternalism, and instead prefer its earlier manifestation promulgated by Thaler and Sunstein (2009).

${ }^{91}$ Goldberg (2002), pp 57-65, 68-70.

${ }^{92}$ Mill (1993), pp 14-15.

${ }^{93}$ Watson (2007a), p 107.
} 
income management. This government rationale can easily fit within the nudge paternalist's notions about defective reasoning needing to be nudged out of certain people deemed incapable of making good choices. ${ }^{94}$ In this sense, nudge paternalism has potential to simply continue colonial domination of Indigenous peoples under a new name.

Thaler and Sunstein maintain that their theory is based upon the idea that 'human behavior can be improved by appreciating how people systematically go wrong'. ${ }^{95}$ What appears to be missing from their analysis is the acknowledgement that law and policy-makers can also 'systematically go wrong'. In fact, throughout Australia's colonial history there is a fairly consistent pattern spanning over 200 years of law and policy-makers getting it wrong in terms of paternalistic law and policy affecting Indigenous peoples. This explains why there is scepticism about the current claim that new forms of paternalism can produce superior outcomes. ${ }^{96}$ Thaler and Sunstein state that paternalistic processes are needed because there are 'systematic biases in the way we think'. ${ }^{97}$ However, it is legitimate to ask - who will monitor the systematic bias of the monitors? Surely these types of bias are no less concerning than the bias of people the monitors claim need paternalism. This raises profound ethical issues in terms of the rights of Indigenous peoples, which could be further marginalised by a framework of nudge paternalism across a range of policy areas.

\section{Problems with Indigenous peoples being nudged towards majoritarian values}

Thaler and Sunstein claim that 'people have a strong tendency to go along with the status quo or default option'. 98 They contend that '[h]umans are easily nudged by other [h] umans. Why? One reason is that we like to conform'. ${ }^{99}$ This may be the case with some people or certain groups of people in relation to particular issues. However, it is far too broad an assumption to apply across all contexts. Indigenous peoples have consistently maintained their right to their own culture and values as opposed to being assimilated into the mainstream. ${ }^{100}$ Indeed, Indigenous peoples have a long history of resistance to colonisation, ${ }^{101}$ and although 'their efforts were commonly misinterpreted as evidence of stupidity or ingratitude, they have been successful in retaining a distinct cultural identity'. ${ }^{102}$ It seems likely that what early colonists saw as evidence of stupidity in refusing to adopt European lifestyles was simply a matter of Indigenous people exercising their preference for their own culture. So it is not simply a matter of just organising the default options in a way

\footnotetext{
${ }^{94}$ Thomas and Buckmaster (2010), p 17. Also, the new paternalist's ideas about unsophisticated people needing paternalistic intervention (Thaler and Sunstein 2009, p 79).

${ }^{95}$ Thaler and Sunstein (2009), p 21.

${ }^{96}$ Behrendt (2007), p 18; Standing (2014b), p 239.

${ }^{97}$ Thaler and Sunstein (2009), p 21.

${ }^{98}$ Thaler and Sunstein (2009), p 8.

${ }^{99}$ Thaler and Sunstein (2009), p 59. This was reiterated to some degree in Sunstein (2013, p 138).

${ }^{100}$ Watson (1997), p 53; Arabena (2006), p 38.

${ }^{101}$ Patton and Ferguson (1999), pp 82-86.

${ }^{102}$ Hollinsworth (2006), p 128.
} 
that will lead to more people choosing the same preordained majoritarian outcome, as nudge paternalists might suggest. Some people may quite rationally want to stand outside of the current dominant value system and adhere instead to their own culture or values. Kerry Arabena explains that 'Indigenous peoples [...] have been resisting what dominant societies see as modernity and have, in many places, been living against it'. ${ }^{103}$ Going with what a particular majority may aspire to is not necessarily going to lead to better outcomes for Indigenous peoples. ${ }^{104}$ However, Thaler and Sunstein's theory on nudge paternalism can have a homogenising impact, negating the validity of different choices that may be more aligned with achieving Indigenous peoples' cultural values and aspirations. Nudge paternalism undervalues diversity in terms of different modes of thinking, and falls into the trap of advocating or assuming that homogeneity either exists ${ }^{105}$ or can be imposed through a series of nudges. It can attempt to manufacture homogeneity via the 'exclusionary disciplining of difference'. ${ }^{106}$ It does not acknowledge the potential for the nudging framework to reproduce patterns of domination and subordination. It also significantly underplays the importance of resistance on the part of those whom the government is attempting to socially engineer.

\section{Part II: How does income management depart from the principles of nudge paternalism?}

Despite the philosophical objections to nudge paternalism discussed in Part I, it is also interesting to note that income management, as it has been implemented in Australia, departs from several principles of nudge paternalism formed by Thaler and Sunstein. As previously mentioned, this is worthwhile reflecting upon due to the growing global influence of nudge paternalism, which may prompt the Australian government to shift from new paternalism towards nudge paternalism at some future point. ${ }^{107}$ Thaler and Sunstein explain that:

A nudge [...] is any aspect of the choice architecture that alters people's behaviour in a predictable way without forbidding any options or significantly changing their economic incentives. To count as a mere nudge, the intervention must be easy and cheap to avoid. Nudges are not mandates. ${ }^{108}$

\section{Compulsory income management imposes mandates}

Compulsory income management does forbid options, there are mandates - there are a range of goods and services that are prohibited expenditure under the BasicsCard. These include alcohol, tobacco, pornographic material ${ }^{109}$ and gambling services. ${ }^{110}$

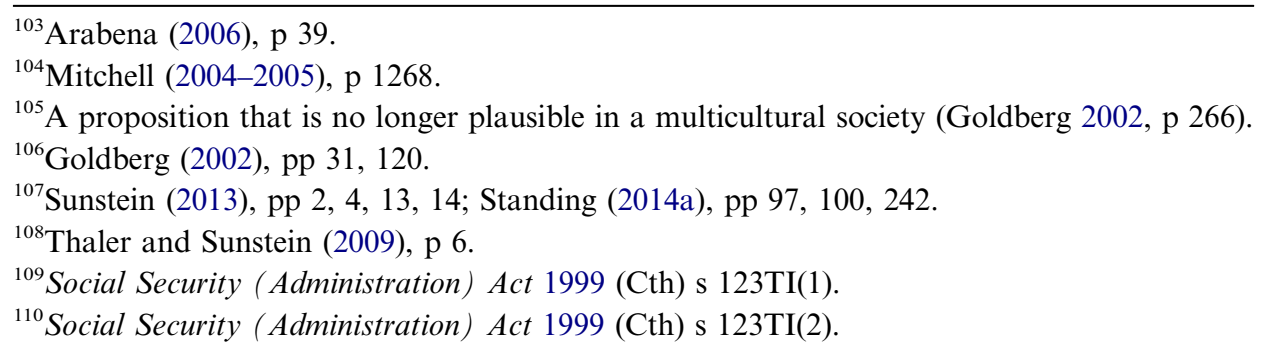


Compulsory income management therefore goes beyond what has been recommended by Thaler and Sunstein. It is also interesting to note that the majority of welfare recipients who are subject to compulsory income management have indicated that they do not have problems with expenditure on these prohibited items. ${ }^{11}$ Yet problematic expenditure in these areas remains central to the government's justification as to why welfare recipients need to be subject to these measures. ${ }^{112}$

The other way in which compulsory income management imposes mandates is by limiting the range of merchants and service providers with whom welfare recipients can spend their managed income using the BasicsCard. This restricts their freedom of contract, as they are no longer free to purchase goods and services of their choice from merchants of their choice. ${ }^{113}$ The BasicsCard can only be spent at government approved stores on government approved 'priority needs'. This has the effect of eliminating some more economically efficient outlets for welfare recipients and adding to the overall cost of their groceries. ${ }^{114}$ This is a serious side effect for those who are struggling to survive on low incomes. The limitations on where the BasicsCard can be spent can also result in some welfare recipients needing to travel further to reach government approved retailers, which involves additional cost for these welfare recipients. ${ }^{115}$ Extra money needs to be spent on fuel to accommodate this paternalistic endeavour, and yet the government does not provide extra income for this purpose, leaving welfare recipients in a difficult situation where they are required to do more with less income. It is unjust that welfare recipients be burdened with these additional costs when they receive such meagre government allowances.

The fact that cheaper food is unavailable for purchase in some areas shows that income management has the effect of prohibiting a range of contracts that would actually be of benefit to some welfare recipients. A government commissioned report on income management found welfare recipients were concerned 'that the limitations of the merchants where BasicsCard is accepted results in people missing out on better deals or fresher food which is available from markets where the BasicsCard is not accepted'. ${ }^{116}$ This prohibition on beneficial contracts is interesting in terms of another criterion for nudge paternalism mentioned by Thaler and Sunstein. They state that if the paternalism 'prohibits contracts that may be mutually beneficial' then it 'does not qualify as libertarian paternalism'. ${ }^{117}$ Thus, the limitation on the range of merchants who can accept the BasicsCard for permitted expenditure fails to qualify as nudge paternalism.

There are also difficulties encountered by welfare recipients seeking to purchase larger household items, which require 'them to organise for Centrelink to make the payment to the retailer'. ${ }^{118}$ One Indigenous woman has described this experience as

\footnotetext{
${ }^{111}$ Bray et al (2012), p 185.

${ }^{112}$ Explanatory Memorandum to the Social Security Legislation Amendment Bill 2011, p 2; Commonwealth of Australia (2011) Parliamentary Debates, House of Representatives, 13540 (Jennifer Macklin).

${ }^{113}$ Bielefeld (2013), p 19.

${ }^{114}$ Bray et al (2012), pp 91-92.

${ }^{115}$ Altman and Hinkson (2010), p 201; Bray et al (2012), p 92.

${ }^{116}$ Bray et al (2012), p 92.

${ }^{117}$ Thaler and Sunstein (2009), p 146.

${ }^{118}$ Bray et al (2012), p 92.
} 
follows: 'They told me at Harvey Norman, Good Guys, and then JB Hi Fi [...] to go to Centrelink and get them to make a cheque and then it takes 3 days for that cheque to get to the shop and that is difficult'. ${ }^{119}$ To require welfare recipients to engage in this permission-seeking process is degrading for them and time consuming. It could also lead to them being perceived as troublesome customers by retailers who have to wait for Centrelink to send a cheque for the goods to be purchased. This could lead to further embarrassment and stigmatisation of welfare recipients when they shop. There is no sound reason why welfare recipients should be put in this position. Consumer purchases occur several times a week in a capitalist society such as Australia. To impose these limitations on consumers who are welfare recipients will involve multiple weekly reminders that the government deems them to be too incompetent to manage their finances. This message is hardly constructive in terms of facilitating the aims the government claims to want to achieve.

The income management scheme also requires welfare recipients to use a BasicsCard to spend their government managed income. This can result in problems for welfare recipients when the BasicsCard system malfunctions and they have no other means of paying for the items. One Indigenous woman described this experience as follows: '[s]ometimes the BasicsCard lines go down [and] it is a shame job, especially when I'm food shopping and I can't pay for the food'. ${ }^{120}$ In this situation income management results in people having 'less [...] cash and hence [they] do not have the cash alternative available to them to the same extent as they would if they were not subject to income management'. ${ }^{121}$ These are serious consequences, and can understandably contribute to higher stress levels for welfare recipients.

\section{Compulsory income management is difficult to avoid}

Another way in which the compulsory income management scheme departs from the criteria for nudge paternalism advocated by Thaler and Sunstein is that it is difficult to avoid. Those seeking an exemption from compulsory income management need to satisfy a range of criteria that can make exemption an unlikely outcome for those who seek it. If a welfare recipient is defined as a "disengaged youth"122 or a 'longterm welfare recipient ${ }^{123}$ then they can seek an exemption if they satisfy the legislative criteria. ${ }^{124}$ One aspect of the exemption criteria that can be particularly challenging for any person on welfare to satisfy is that there must have been 'no indications of financial vulnerability' in the preceding 12 months. ${ }^{125}$ Among other things, whether a welfare recipient can meet their 'priority needs' and whether they have needed 'urgent payments' are factors that can be taken into account when assessing 'financial vulnerability'. ${ }^{126}$ These factors can have the effect of widening

\footnotetext{
${ }^{119}$ Bray et al (2012), p 93.

${ }^{120}$ Bray et al (2012), p 93.

${ }^{121}$ Bray et al (2012), p 93.

${ }^{122}$ Social Security (Administration) Act 1999 (Cth) s 123UCB.

${ }^{123}$ Social Security (Administration) Act 1999 (Cth) s 123UCC.

${ }^{124}$ Social Security (Administration) Act 1999 (Cth) ss 123UGC, 123UGD.

${ }^{125}$ Social Security (Administration) Act 1999 (Cth) s 123UGD(1)(d).

${ }^{126}$ Commonwealth Ombudsman (2012), pp 8-9.
} 
the compulsory income management net, because welfare recipients are living 'on incomes below the poverty line'. ${ }^{127}$

Another difficulty is that bureaucrats responsible for administering the exemption system can engage in paternalism and discrimination when exercising their discretion. ${ }^{128}$ Such discrimination makes it incredibly difficult for Indigenous people to get an exemption and resume financial control over their spending patterns. Indigenous people have found the exemption process particularly difficult to negotiate successfully. ${ }^{129}$ Non-Indigenous people have had far more exemptions granted than Indigenous people seeking an exemption. The Australian Law Reform Commission noted in 2011 that only 25 per cent of Indigenous people were granted exemptions, whereas non-Indigenous people were granted 75 per cent of exemptions. ${ }^{130}$ Thus, 'non-Indigenous welfare recipients, who make up just 4 per cent of the entire population on quarantined payments in the NT, accounted for three quarters of all exemptions granted'. ${ }^{131}$

Moralistic judgements about the capacity or behaviour of welfare recipients can also go against them as they undertake the process of trying to attain an exemption. To attain an exemption 'requires much more than a person being able to demonstrate their ability to manage their finances in a responsible manner. The program can thus be seen as effectively creating an imposition on people where they fail to behave in desired ways'. ${ }^{132}$ The prospect of Eurocentric values affecting the judgements made about what constitutes desirable behaviour are significant, and yet this is not directly addressed in any of the government commissioned evaluations on the impact of income management on Indigenous peoples.

Attaining the requisite documentation to prove that they satisfy the exemption criteria is another challenging aspect of the process for Indigenous welfare recipients. ${ }^{133}$ Other challenges faced by Indigenous welfare recipients throughout the exemption process include 'lack of knowledge as to how to attain an exemption, difficulties in the exemption process, English language issues, inaccurate information provided by third parties, and lack of flexibility in the legislative exemption requirements'. ${ }^{134}$ It is worth noting that if a welfare recipient does manage to overcome the hurdles and attain an exemption from compulsory income management, they have to go back to Centrelink to seek another exemption after 12 months. ${ }^{135}$ This sets in place a system of never-ending micromanagement for welfare recipients. They therefore have to keep making substantial efforts if they hope to

\footnotetext{
${ }^{127} \operatorname{Cox}(2011), \mathrm{p} 69$.

${ }^{128}$ Gibson (2010), pp 2-3; Australian Law Reform Commission (2011), p 265.

${ }^{129}$ Bray et al (2012), p 254.

${ }^{130}$ Australian Law Reform Commission (2011), p 265.

${ }^{131}$ National Welfare Rights Network, Submission CFV 150 in Australian Law Reform Commission (2011), p 266

${ }^{132}$ Bray et al (2012), p 114.

${ }^{133}$ Bray et al (2012), p 114.

${ }^{134}$ Australian Law Reform Commission (2011), p 266; Equality Rights Alliance (2011), p 36; Bielefeld (2012), p 549.

${ }^{135}$ Billings and Cassimatis (2010), p 67.
} 
exercise autonomy in regards to their spending patterns. ${ }^{136}$ For many Indigenous peoples, this resonates with Australia's earlier colonial laws and policies involving paternalistic control over access to cash payments and triggers trauma about their stolen wages. ${ }^{137}$

\section{Income management does not genuinely facilitate 'free choice'}

Thaler and Sunstein state that '[f]reedom to choose is the best safeguard against bad choice architecture'. ${ }^{138}$ This sounds good in theory, but the government can tend to pay more attention to the paternalistic aspects of their theory rather than this notion of preserving freedom of choice. If freedom of choice were genuinely implemented in the income management scheme it would be less problematic. However, there are currently impediments to genuine freedom of choice. There are numerous people subject to compulsory income management, but even the so-called 'voluntary' form is problematic. The 'voluntariness' of welfare recipients who choose income management has been questioned by various stakeholders who contend that the current scheme is "not a truly "voluntary" scheme, in form or substance'. ${ }^{139}$ An additional $\$ 500$ per year can be attained by those who 'volunteer' for income management, ${ }^{140}$ which raises questions about the voluntariness of the scheme, because offering additional money to people living below the poverty line clearly provides an economic incentive for people to choose it. In practical terms, the provision of this economic incentive qualifies as a limitation on choice. To tell welfare recipients that they have a choice to receive less income when they are living in impoverished circumstances is really no choice at all. The additional income obtainable via voluntary income management can therefore be seen as 'significantly changing' the 'economic incentives' of welfare recipients. ${ }^{141}$ This highlights that there can be serious problems in terms of how the government conceptualises choice and voluntariness. ${ }^{142}$ Another way in which the income management scheme does not genuinely facilitate free choice is seen in the previously mentioned limitations placed upon freedom of contract.

\section{Compulsory income management involves coercive paternalism rather than gentle nudges}

Whilst Thaler and Sunstein are advocates of 'the gentle power of nudges', ${ }^{143}$ the danger is that a nudge in theory can transform into a moralistic push in practice 'directing people to behave in ways deemed by the policymakers as best for themselves and for society'. ${ }^{144}$ This is already occurring in the United Kingdom in

\footnotetext{
${ }^{136}$ Billings and Cassimatis (2010), p 67.

${ }^{137}$ Kidd (2006), Chapters 4-5; Gibson (2009), pp 12-13, 18.

${ }^{138}$ Thaler and Sunstein (2009), p 12.

${ }^{139}$ Australian Law Reform Commission (2011), pp 271-272.

${ }^{140}$ Made in two $\$ 250$ payments for each 6 months, Australian National Audit Office (20122013), p 14; Mendes et al (2013), p 13.

${ }^{141}$ Thaler and Sunstein (2009), p 6.

${ }^{142}$ Standing (2014a), p 292.

${ }^{143}$ Thaler and Sunstein (2009), p 9.

${ }^{144}$ Standing (2014a), pp 100, 242.
} 
the welfare reform context as a consequence of 'the Nudge Unit'. ${ }^{145}$ As previously mentioned, nudge paternalists have shifted the policy debate towards a more limited choice between hard paternalism and soft paternalism, and thereby opened up a discourse where further paternalism can be rationalised as a legitimate 'helping' mechanism. This prospect is apparent in the Explanatory Memorandum for the Social Security Legislation Amendment Act 2012 (Cth), mentioned earlier, which refers to the paternalism embedded in the income management scheme as 'supportive'. Yet the Australian government has adopted paternalistic pathways that are perceived by many of those subject to them as coercive and punitive. ${ }^{146}$ There is nothing gentle about paternalism that can leave people significantly worse off financially as they travel greater distances to shop using their BasicsCards at government approved locations. ${ }^{147}$ Checking the balance of BasicsCards can also be a costly exercise when people use mobile phones, ${ }^{148}$ yet ironically, paying mobile phone bills is not included in the legislative list of government approved 'priority needs'. There is also nothing gentle about an approach that leaves welfare recipients to bear the burden of shame and stigmatisation that can occur at the point of sale. ${ }^{149}$ An example of the stigmatisation that can take place when people shop under income management is seen in the following statement by a Centrelink officer who referred to 'incidences in the supermarkets where the [sales assistant] would tell the customer, no, oh well you are on that card, you can't have that steak. You go and get that other steak, that cheaper one. You are wasting your money'. ${ }^{150}$ This type of experience is acutely embarrassing for welfare recipients. Experiences of this kind are likely to have a negative impact on the wellbeing of welfare recipients. They could also have a negative impact upon the children of welfare recipients who watch parents being humiliated at the point of sale.

\section{Compulsory income management applies to large categories of welfare recipients regardless of their personal budgetary capacities without addressing their specific needs}

Thaler and Sunstein claim '[a] good choice is one that meets a person's specific needs'. ${ }^{151}$ However, income management deems large numbers of people to be financially incompetent unless they can prove that they have adequate budgetary skills ${ }^{152}$ and can meet the socially responsible behaviour criterion. ${ }^{153}$ In this way, the compulsory income management scheme pre-emptively presumes that people in receipt of welfare payments in the designated categories lack budgetary capacities and/or are socially irresponsible - until proven otherwise. This is underpinned by a very value laden framework about what virtues are presumed to be lacking in

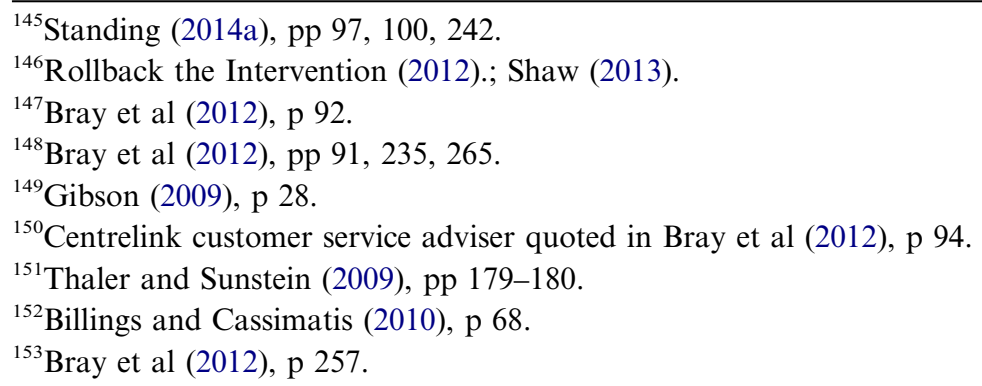


welfare recipients. ${ }^{154}$ Under the compulsory income management scheme the burden of proof falls on those who are most marginalised by society to demonstrate that they are virtuous enough to be accorded the privilege of managing their own budget. They are subject to random restrictions on their freedom of contract ${ }^{155}$ based upon a whole series of assumptions that are not borne out by evidence. This does not meet their specific needs.

\section{Compulsory income management has caused harm to some welfare recipients and has failed to help numerous others}

Thaler and Sunstein state 'the golden rule of libertarian paternalism' is to 'offer nudges that are most likely to help and least likely to inflict harm'. ${ }^{156}$ However, compulsory income management has caused harm to some welfare recipients. It is not as unequivocally beneficial as the government suggests. ${ }^{157}$ In the second reading speech of the Stronger Futures laws Minister Macklin stated:

The introduction of the basics card has been positive, showing that income management is a useful tool for people. It has helped them to stabilise the family budget and make sure that money is being spent on housing, food and clothing for children. ${ }^{158}$

Yet there were several reports completed by that time pointing out problems with income management, including health problems, ${ }^{159}$ in stark contrast to the statement made by Macklin that income management had been 'positive'. Another example of the positive gloss that parliamentarians place upon income management is seen in Prime Minister Tony Abbott's comment that income management has proven to be 'right in the Territory so can hardly be wrong elsewhere'. ${ }^{160}$ This ignores the fact that income management has caused considerable stress for some of those who are subject to it, including 'medical problems' in the form of 'heart palpitations'. ${ }^{161}$

For many welfare recipients, income management has also failed to demonstrate the kinds of benefits it was introduced to achieve. For example, the Equality Rights Alliance found that 85 per cent of those surveyed said they did not change what they purchased as a result of being income managed. ${ }^{162}$ However, 53 per cent did say that

\footnotetext{
${ }^{154}$ Mendes (2013), p 495.

${ }^{155}$ Bielefeld (2013), p 19.

${ }^{156}$ Thaler and Sunstein (2009), p 79.

${ }^{157}$ Commonwealth of Australia (2009) Parliamentary Debates, House of Representatives, 12784 (Jennifer Macklin); Australian Government (2011), p 21; Commonwealth of Australia (2011) Parliamentary Debates, House of Representatives, 13540 (Jennifer Macklin); Farr (2011).

${ }^{158}$ Commonwealth of Australia (2011) Parliamentary Debates, House of Representatives, 13540 (Jennifer Macklin).

${ }^{159}$ Gibson (2009) pp 12-13, 18; Australian Indigenous Doctors' Association and Centre for Health Equity Training (2010), p 25; Equality Rights Alliance (2011), p 19.

${ }^{160}$ Farr (2011).

${ }^{161}$ Australian Indigenous Doctors' Association and Centre for Health Equity Training (2010), p 25; Equality Rights Alliance (2011), p 19.

${ }^{162}$ Equality Rights Alliance (2011), p 40.
} 
shopping was frequently more difficult using the BasicsCard. ${ }^{163}$ Moreover, when asked how they felt about using the BasicsCard, '79\% answered I do not like using the BasicsCard and want to stop using it now'. ${ }^{164}$ These comments are indicative of a high level of dissatisfaction with the BasicsCard for many of those surveyed who have to use it as a result of income management.

Furthermore, in 2012 Bray and others found that 'there is little indication that income management is itself effective in changing parenting behaviour, reducing addiction or improving capacity to manage finances'. ${ }^{165}$ Their report concluded that stress and shame were consequences of income management. ${ }^{166}$ They stated that ' $[\mathrm{t}]$ he BasicsCard was frequently seen as stigmatising because it identified people as being deficient'. ${ }^{167}$ Bray and others reported that:

\begin{abstract}
Many stakeholders spoke about people feeling embarrassed or shamed by having to use the BasicsCard for shopping. [...] In Darwin some women were reported as doing their shopping away from their local area because they don't want to be seen with their BasicsCard. It was suggested that some single mothers see it as providing a visible marker of being a bad parent. Similarly, some stakeholders reported that older women felt ashamed by the implications they cannot manage money or that they misuse alcohol or gamble. ${ }^{168}$
\end{abstract}

Although Bray and others noted that responses to income management were mixed, they quoted one Indigenous woman who stated 'depression and other added stresses from [...] income management [...] is making it harder'. ${ }^{169}$ They quoted another who said income management is 'really embarrassing people'. ${ }^{170}$ In a similar vein, Bev Manton described income management as 'a degrading, humiliating and pride-sapping emotional whipping of the highest order'. ${ }^{171}$ This raises significant issues about the wellbeing of welfare recipients who are subject to income management. Income management reduces autonomy and can foster feelings of shame in welfare recipients, who are treated as though they are not 'the moral equal of others'. ${ }^{172}$ By shaming welfare recipients, compulsory income management has the capacity to undermine 'attitudes of self-respect, self-trust, and self-esteem' which are essential for autonomy. ${ }^{173}$

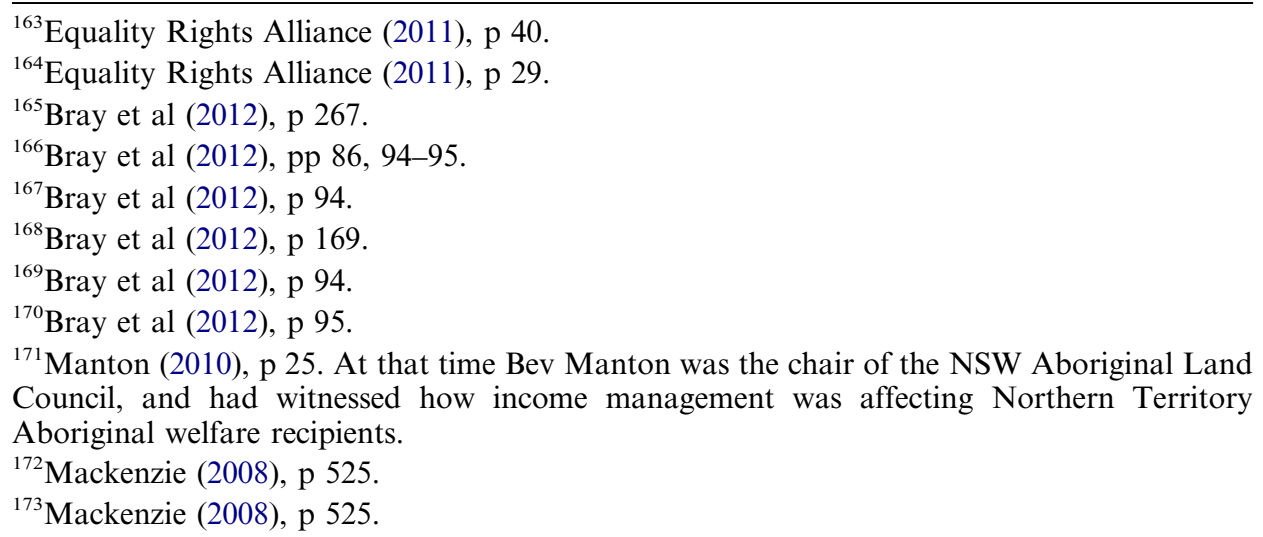




\section{Part III: Suggestions for social policy initiatives to address disadvantage}

Due to the problems with paternalistic policy-making directed towards Indigenous peoples, including nudge paternalism, identified in Part I, and the problems with hard paternalism in the income management context, identified in Part II, alternative policy frameworks need to be explored. There are means by which the government could seek to improve the socioeconomic disadvantage Indigenous peoples experience that do not involve nudge paternalism, or other forms of paternalism such as new paternalism. The following suggestions are a starting point to consider in terms of travelling in a different policy direction.

\section{Take all consequences of laws and policies into consideration when assessing their value and respond to ethical concerns}

The consequences of law and policy measures deserve rigorous scrutiny. However, in official government income management evaluations there has been a tendency to focus on benevolent government intentions at the expense of negative consequences, or to only explore a limited range of consequences. ${ }^{174}$ Sarah Maddison explains that, 'perversely, even the most damaging of Australia's policies towards Indigenous people have been excused as failed attempts at improving their quality of life'. ${ }^{175}$ Yet it is important to remember that 'harmful effects are harmful regardless of the intent with which they are produced'. ${ }^{176}$ It is important to realise that unethical behaviour can still occur when law and policy-makers cause harm but do so with the best of intentions. A multitude of ethical concerns have been raised about the operation of compulsory income management, ${ }^{177}$ including the way that it leads to disempowerment and depression for a significant number of Indigenous people subject to it. ${ }^{178}$ These ethical concerns need to be addressed by the government instead of ignored. Repealing the compulsory income management categories would be a good starting point.

\section{Take into account the structural causes of disadvantage and address those rather than just transferring risk and responsibility to individual welfare recipients}

In terms of structural issues contributing to disadvantage for Indigenous peoples in the Northern Territory, the government needs to invest heavily to compensate for decades of fiscal neglect and 'support innovative programs to enable local livelihood opportunity'. ${ }^{179}$ Jon Altman argues that this is part of 'the essential citizenship catch-up' necessary to redress disadvantage for Aboriginal people in the Northern Territory. ${ }^{180}$ The structural causes of disadvantage experienced by Aboriginal people in the Northern Territory are immense. Philip Mendes and others note that no

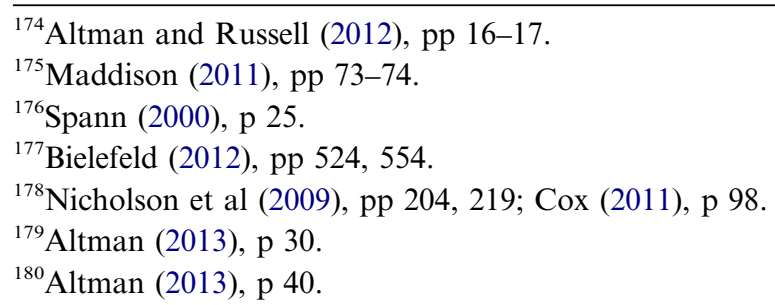


official evaluations of income management to date have really taken into consideration 'the structural barriers to maximizing income for the person on a low income'. ${ }^{181}$ This also needs to be addressed in order to develop a more complete picture of the causes of poverty experienced by welfare recipients. It is inadequate to simply assume fault on the part of welfare recipients in regards to spending patterns without taking into account the broader structural issues that perpetuate disadvantage. ${ }^{182}$ The government should address the 'structural causes' of disadvantage faced by Indigenous peoples, ${ }^{183}$ rather than simply transferring risk and responsibility onto individual welfare recipients, ${ }^{184}$ as occurs with compulsory income management.

\section{Facilitate more community involvement rather than impose further paternalistic colonial governance}

There have been successful examples of Aboriginal community driven approaches which deal with the budgetary management issues the government claims to address with contemporary income management. Indeed, purely voluntary forms of income management have been in use in some remote Northern Territory communities long before the government introduced the BasicsCard. For example, in Alice Springs, voluntary income management has been in existence since the 1980s in the form of food vouchers. The Tangentyere Council explain that:

Tangentyere is proud of this Service which was founded by the Town Campers $[. .$.$] in$ the early 1980s and is an example of voluntary income management that was established many years before the NT Intervention. It was, and still is, a Voluntary system that allows Town Campers to choose how much of their Centrelink funds they want to put towards food each fortnight as part of their own Income Management and Budgeting Plans. Town Campers always knew how to solve their own Feast and Famine problems and as the bosses of Tangentyere, were able to get the expertise to put this enduring system in place. It is their system and they proudly own it. ${ }^{85}$

The Arnhemland Progress Aboriginal Corporation (APLA) also developed a FOODCard which 'evolved from community consultations at Gapuwiyak in 2004'. ${ }^{186}$ This initiative was developed with '[e]xtensive community consultation' and items able to be purchased 'included most grocery food items and baby requirement[s] in line with ALPA's healthy choice policy. Excluded items include soft drinks, cigarettes, tobacco and toys'. ${ }^{187}$ The FOODCard is voluntary, and is 'a good [...] example of a "bottom up" community approach in tackling a difficult

\footnotetext{
${ }^{181}$ Mendes et al (2013), p 30.

${ }^{182}$ Mendes (2013), p 495.

${ }^{183}$ Australian Human Rights Commission (2012), p 19.

${ }^{184}$ Marston et al (2010), pp x-xi; Moss (2010), pp 129, 138.

${ }^{185}$ Tangentyere Council Incorporated (2012), p 14.

${ }^{186}$ Arnhemland Progress Aboriginal Corporation, 'APLA FOODCARD' http://www.alpa. asn.au/pages/ALPA-FOODcard.html. Accessed 23 November 2014.

${ }^{187}$ Arnhemland Progress Aboriginal Corporation, 'APLA FOODCARD' http://www.alpa. asn.au/pages/ALPA-FOODcard.html. Accessed 23 November 2014.
} 
social problem'. ${ }^{188}$ These examples highlight that Aboriginal communities have more capacity to create effective and culturally appropriate forms of budgetary management support than government paternalists acknowledge.

Evidence suggests that law and policy affecting Indigenous peoples requires community driven approaches rather than imposed government approaches. Community driven approaches have a greater chance of effectively meeting the needs of local communities, a greater chance of success than paternalistic 'top down' government approaches. ${ }^{189}$ Yet the government appears not to have consulted with a range of communities who were affected by the 2012 extensions to the income management scheme. ${ }^{190}$ Proper consultation with all affected communities is essential. For well-designed social policy initiatives it is crucial that government engage properly with Indigenous communities about social and economic issues affecting them. ${ }^{191}$ Mendes and others state:

There is overwhelming evidence of the importance of local control and involvement in problem identification, program design and decision-making. Many evaluations of services in Indigenous communities have shown that they are most effective when the community is heavily involved in both the planning and implementation stages. ${ }^{192}$

This has not occurred with the income management scheme applied in the Northern Territory. Nor has it occurred in relation to the expansion of aspects of that scheme in the trial sites. ${ }^{193}$ There was no consultation with Aboriginal communities in the Northern Territory about any aspects of the Intervention, including income management, when it was rolled out in 2007. In the 2009 Future Directions for Northern Territory Emergency Response consultations Aboriginal communities were only provided with the option to continue income management in one of two modes - with exemptions or without exemptions - rather than being provided with an option for it to be abolished or made purely voluntary. ${ }^{194}$ The consultations 'were carried out within a framework in which the continuation of income management of some sort was presented as inevitable', ${ }^{195}$ highlighting problems with how the government conceptualises choice. By the time the 2011 Stronger Futures consultations took place, the government had redefined income management as a welfare reform measure, and therefore did not allow for further consultation on the topic of income management, ${ }^{196}$ despite there being evidence of strong criticism of income

\footnotetext{
${ }^{188}$ Mendes et al (2013), pp 25, 29.

${ }^{189}$ Behrendt (2007), p 16; Brigg and Maddison (2011), p 6; Mendes et al (2013), pp 29-30.

${ }^{190}$ Rollback the Intervention (2012); Parliamentary Joint Committee on Human Rights (2013), p 60.

${ }^{191}$ Rollback the Intervention (2012); Altman (2013), p 102.

${ }^{192}$ Mendes et al (2013), p 29. Internal references omitted.

${ }^{193}$ Mendes et al (2013), p 29; Parliamentary Joint Committee on Human Rights (2013), p 60.

${ }^{194}$ Australian Council of Social Services, 'Submission to Senate Community Affairs Legislation Committee: Inquiry in Social Security and Other Legislation Amendment (Welfare Reform and Reinstatement of Racial Discrimination Act) Bill 2009 and related Bills (2010) in Cox (2011), pp 30-31; Vivian (2010), p 62.

${ }^{195}$ Bielefeld (2012), p 542.

${ }^{196}$ Department of Families, Housing, Community Services and Indigenous Affairs (2011), p 7.
} 
management by Indigenous peoples, ${ }^{197}$ and knowledge that income management overwhelmingly still applied to Indigenous peoples.

Undoubtedly, if the government were working with Indigenous communities it would be more time consuming and resource intensive than the current approach involving rushed consultation timeframes. For example, a paltry 6 week consultation period was allocated with Northern Territory Aboriginal communities before the Stronger Futures laws were hurried through parliament. ${ }^{198}$ These laws are in place for a decade, but a minimal timeframe was dedicated to consultations with those who would be affected by them. The Aboriginal and Torres Strait Islander Social Justice Commissioner, Mick Gooda, has criticised the rushed timeframe for the Stronger Futures consultations, stating that they 'commenced only a few days after the discussion paper was released' and only 'allowed for [...] superficial feedback'. ${ }^{199}$

The Australian Human Rights Commission has set out guidelines for effective and culturally appropriate engagement with Aboriginal and Torres Strait Islander peoples that the government would do well to follow. These include '[r]ecognition and regard for Indigenous peoples' rights', '[r]espect for Indigenous culture and difference, particularly decision making processes' and ensuring 'Indigenous peoples' free, prior and informed consent'. ${ }^{200}$ When compared to these ethical guidelines, the approach adopted by the government in its 2009 and 2011 consultations is inadequate. It is crucial that future government consultations and evaluations conform to international human rights standards. Failure to do so will further entrench the disadvantage experienced by Indigenous peoples. It is also important 'not to generalise from understandings of one Indigenous community to others or to all Indigenous peoples'. ${ }^{201}$ This means that the ethical approach for government is not to assume that what works for one Aboriginal community is necessarily going to work for another Aboriginal community. So if there is one Aboriginal community that wants income management, it should not therefore be assumed that income management is necessarily the best or most appropriate way to resolve social challenges faced by other Aboriginal communities. The problems that can arise in situations where the government subscribes to generalisations about Aboriginal communities with a 'generic, one size fits all approach' was colourfully described by one Stronger Futures consultation participant in the following way:

I think we have to be very careful about taking a banana smoothie approach. What I'm concerned about is that after listening [to] their own situations, to so many people each with their unique take, you can't just take all these ideas and just chuck them together

\footnotetext{
${ }^{197}$ Gibson (2009), pp 11-12, 16, 18; Annexure B - Bagot Community Darwin, NT Transcript of FHCSIA 'Special Measures' Consultations: 'Future Directions for Northern Territory Emergency Response' 28 July 2009 in Nicholson et al (2009), pp 82, 86; Annexure D Arlparra/ Utopia Northern Territory Transcript of FHCSIA 'Special Measures' Consultations: 'Future Directions for Northern Territory Emergency Response' 13 August 2009 Part 1 in Nicholson et al (2009), pp 172-173.

${ }^{198}$ Australian Human Rights Commission (2011), p 27.

${ }^{199}$ Australian Human Rights Commission (2011), p 27.

${ }^{200}$ Australian Human Rights Commission (2012), p 19. The last factor mentioned mirrors Article 19 of the United Nations Declaration on the Rights of Indigenous Peoples 2007.

${ }^{201}$ Australian Institute of Aboriginal and Torres Strait Islander Studies (2012), p 2.
} 
and turn on the blender and come out with something that you can dish out to everybody that will work in every situation because Indigenous cultures are unique, languages are unique, people are unique, communities are unique, families are unique and unless the consultation process means an ongoing conversation with individuals, community groups, families as well as the community as a whole [...] I think it runs the risk of being wasted. ${ }^{202}$

\section{Respect the right of Australia's First Peoples to self-determination}

The right to self-determination affects a range of concerns for Indigenous peoples across many policy areas, including rights to land, culture, language, health, welfare and criminal justice issues. ${ }^{203}$ Discussion of these numerous issues is outside the scope of this article; however, some points about the importance of respecting the collective right of Indigenous peoples to self-determination will be made. Selfdetermination requires more than involving Indigenous communities in policymaking that affects them. It involves more than conducting consultations with Indigenous communities and then going ahead with a predetermined policy agenda as though the consultation process were a mere formality. ${ }^{204}$ As Morgan Brigg and Lyndon Murphy point out, '[t]o frame problems in liberal terms, as tends to happen at the beginning of the policy process, and to then have Indigenous people own and participate in subsequent processes does not equate with credible Indigenous ownership'. ${ }^{205}$

In ascertaining how to move forward in terms of addressing Indigenous disadvantage, Sol Bellear, chair of the Aboriginal Medical Service in Redfern, has pertinent suggestions in terms of promoting self-determination rather than more paternalism. This would take governance beyond mere consultation with Indigenous communities. Bellear maintains that:

The great lie of 100-plus years of Australian Indigenous Affairs policies has always been that Aboriginal people are so backward that we need to be saved from ourselves. [...] That great lie still underpins thinking in Indigenous affairs policy today. So it's time to do something different, and time to acknowledge that the case for self-determination for Aboriginal people in Australia isn't just compelling - it's overwhelming. ${ }^{206}$

There have frequently been misunderstandings in Australia about what constitutes self-determination for Indigenous peoples. The right to self-determination that many Indigenous peoples want the colonial government to recognise extends beyond that of Australia's formal 'self-determination era', where policies were 'more concerned with organisational and community management than with placing meaningful political and economic power in Aboriginal hands'. ${ }^{207}$ Larissa Behrendt

\footnotetext{
${ }^{202}$ Nicholson et al (2012), pp 55, 105.

${ }^{203}$ Behrendt (2003), pp 90-92; Altman (2013), p 102; Anthony (2013), pp 1-209; Bielefeld (2014), pp 16, 18.

${ }^{204}$ Rollback the Intervention (2012).

${ }^{205}$ Brigg and Murphy (2011), pp 28-29.

${ }^{206}$ Bellear (2013), p 4.

${ }^{207}$ Brigg and Maddison (2011), p 6.
} 
explains that, for Aboriginal peoples, 'the right to self-determination has become a powerful description of the notion of deciding our own future'. ${ }^{208}$ Likewise, Michael Mansell states '[s]elf-determination gives Aboriginal people the right to determine our own destiny'. ${ }^{209}$ The fact that self-determination is not likely to produce instantaneous solutions should be no barrier to a change in policy direction in this area. Bellear asserts that:

The solution [...] is for the Australian Government to [...] step back and let us make decisions for ourselves. [...] Over the course of that journey [...] we will make many of the same mistakes that have been made - and continue to be made every single day - by mainstream Australian political and governance structures. [...] But [...] over time, the advances we make will be far greater than those under a system of colonial occupation. How do I make this guarantee? Because we could hardly do any worse, and because decades of international experience, research and outcomes tell us so. ${ }^{210}$

Although Thaler and Sunstein would suggest that the likelihood of mistakes means that nudge paternalism is appropriate, these comments by Bellear highlight the application of a double standard where Indigenous peoples have frequently been held far more accountable for any perceived errors of judgement than the government. These mistakes are then claimed as evidence that Indigenous peoples are not capable of governing their own lives. This trend needs to be redressed. It is fair to say, however, that the Australian government appears to be a long way off acknowledging the collective right of Indigenous peoples to self-determination contained in Article 3 of the United Nations Declaration on the Rights of Indigenous Peoples (UNDRIP). ${ }^{211}$ Indeed, as shown by the gross overrepresentation of Indigenous peoples in the income management categories, the government is still grappling with the idea that Indigenous welfare recipients as individuals have the capacity to manage their own budgets, let alone coming to terms with the complexity of Indigenous peoples having a collective right to self-determination. However, there is a vested interest in the colonial government characterising so many Indigenous welfare recipients in this negative way. ${ }^{212}$ Indigenous peoples portrayed as too irresponsible and inept to govern their own individual budgets may be more readily characterised as lacking the capacity to participate in collective self-determination.

\section{Conclusion}

There are inherent problems with ongoing paternalistic styles of governance affecting Indigenous peoples. As there is a long history of paternalism failing Indigenous

\footnotetext{
${ }^{208}$ Watson (1997), p 55; Behrendt (2001), p 856.

${ }^{209}$ Mansell (2007), p 80.

${ }^{210}$ Bellear (2013), p 5.

${ }^{211}$ For the difference between this and the more robust rights set out in the Declaration of Principles (Indigenous Draft Principles) see Venne (2011), pp 568-570; Churchill (2011), p 538. Australia, along with Canada, New Zealand and the United States had initially voted against the UNDRIP. Although Australia later changed its position in 2009, Australia has not since sought to implement the terms of the UNDRIP in any meaningful way into domestic law.

${ }^{212}$ Figures submitted to the federal parliament in February 2014 confirm that Indigenous peoples grossly outnumber non-Indigenous welfare recipients Australia-wide in the income management categories (Senate Estimates 2014, p 1).
} 
peoples, even a soft form of paternalism such as nudge paternalism is likely to be problematic in terms of effectively addressing their needs in a culturally appropriate manner. The discourse constructed by nudge paternalism is particularly problematic in that it portrays some form of paternalism as inevitable, shifting the focus away from other alternatives that are more culturally appropriate and desirable for Indigenous peoples, such as self-determination. ${ }^{213}$ Nudge paternalists have shifted the policy debate away from the question of whether paternalism is desirable or acceptable, and towards a more limited choice between hard paternalism and soft paternalism. This does not acknowledge that for many Indigenous peoples no form of paternalism is likely to meet with endorsement given the historical and contemporary abuses of power facilitated by paternalistic law and policy.

Paternalism, be it soft or hard, is problematic when directed towards Indigenous peoples. However, Australia is not even choosing a soft form of paternalism in the current income management scheme. Income management departs from many of the theoretical principles of nudge paternalism. This is worthy of consideration in case the government contemplates a shift from new paternalism towards an approach more consistent with nudge paternalism. However, as this article makes clear, there are insurmountable problems with the application of nudge paternalism to Indigenous peoples, whose unique cultural identities and rights need to be respected. The tenets of nudge paternalism are fundamentally incompatible with self-determination. To try to 'nudge' Indigenous peoples into a neoliberal version of 'normality' is still a form of assimilation that is bound to meet with resistance on the part of many of those whom the government is trying to socially engineer. ${ }^{214}$

More paternalism is not the answer to resolving longstanding socioeconomic challenges faced by Indigenous peoples. This article has contributed some alternative suggestions to reflect upon in terms of a different policy direction. First, take all consequences of laws and policies into consideration when assessing their value, including the negative consequences, and respond to ethical concerns in an appropriate manner. Second, take into account the structural causes of disadvantage and address those rather than just transferring risk and responsibility to individual welfare recipients. Third, facilitate more community involvement rather than imposing further paternalistic colonial governance. Finally, respect the right of Australia's First Peoples to self-determination and ensure that government policy frameworks are compatible with this right. The need to improve the socioeconomic circumstances of Indigenous peoples is undeniable, but the method adopted to facilitate such improvement needs to be culturally appropriate, effective and empowering. The shameful stigmatising methods of compulsory income management are unlikely to achieve these outcomes.

\section{Acknowledgements}

This article was prepared in response to an invitation to speak at the conference on Paternalism and Social Policy held at the Centre for Agency, Values and Ethics at Macquarie University on 8 November 2013. The author is indebted to the participants of that workshop,

$\overline{{ }^{213} \text { Calma (2007), p 284; Churchill (2011), pp 540, 543; Venne (2011), pp 568, 573; Watson }}$ (2011), p 508.

${ }^{214}$ Altman (2012a), p xiv; Howard-Wagner (2012), pp 234-236; Altman (2013), pp 140. 
Dr Marina Nehme, and the anonymous reviewers for their constructive comments on an earlier draft of this article, and thanks them for their feedback.

\section{References}

Primary sources

Legislation

Racial Discrimination Act 1975 (Cth)

Stronger Futures in the Northern Territory Act 2012 (Cth)

Stronger Futures in the Northern Territory (Consequential and Transitional Provisions) Act 2012 (Cth)

Social Security (Administration) Act 1999 (Cth)

Social Security Legislation Amendment Bill 2011

Social Security Legislation Amendment Act 2012 (Cth)

Social Security and Other Legislation Amendment (Welfare Reform and Reinstatement of Racial Discrimination Act) Act 2010 (Cth)

Social Security and Other Legislation Amendment (Welfare Payment Reform) Act 2007 (Cth)

Social Security (Administration) (Exempt Welfare Payment Recipients - Persons with Dependent Children) (Indications of Financial Vulnerability) Principles 2010

Social Security (Administration) (Vulnerable Welfare Payment Recipient) Principles 2010

Social Security (Administration) (Vulnerable Welfare Payment Recipient) Principles 2013

Parliamentary debates

Commonwealth of Australia (2007) Parliamentary Debates, House of Representatives, 7 August

Commonwealth of Australia (2009) Parliamentary Debates, House of Representatives, 25 November

Commonwealth of Australia (2011) Parliamentary Debates, House of Representatives, 23 November

International instruments

International Covenant on Civil and Political Rights, opened for signature 19 December 1966, 999 UNTS 171 (entered into force 23 March 1976)

International Covenant on Economic, Social and Cultural Rights, opened for signature 16 December 1966, 993 UNTS 3 (entered into force 3 January 1976)

International Convention on the Elimination of All Forms of Racial Discrimination, opened for signature 21 December 1965, 660 UNTS 195 (entered into force 4 January 1969)

United Nations Declaration on the Rights of Indigenous Peoples, GA Res 61/295, UN GAOR, 61st sess, 107th plen mtg, Supp No 49, UN Doc A/RES/61/295 (13 September 2007)

\section{Secondary sources}

Jon Altman (2011) 'A Genealogy of "Demand Sharing": From Pure Anthropology to Public Policy', in Y Musharbash and M Barber (eds) Ethnography \& the Production of Anthropological Knowledge, ANU E Press.

Jon Altman (2012a) 'Foreword', in N Fijn et al (eds) Indigenous Participation in Australian Economies II: Historical Engagements and Current Enterprises, ANU E Press.

Jon Altman (2012b) 'People on Country as Alternative Development', in J Altman and S Kerins (eds) People on Country - Vital Landscapes - Indigenous Futures, Federation Press. Jon Altman (2013) 'Arguing the Intervention' 14 Journal of Indigenous Policy 1.

Jon Altman and Melinda Hinkson (2010) 'Very Risky Business: The Quest to Normalise Remote-Living Aboriginal People', in G Marston et al (eds) Risk, Welfare and Work, Melbourne University Press.

Jon Altman and Susie Russell (2012) 'Too Much "Dreaming": Evaluations of the Northern Territory National Emergency Response Intervention 2007-2012' 3 Evidence Base 1.

Thalia Anthony (2013) Indigenous People, Crime and Punishment, Routledge.

Kerry Arabena (2006) 'The Universal Citizen: An Indigenous Citizenship Framework for the Twenty-First Century' 2 Australian Aboriginal Studies 36. 
Australian Government (2011) Closing the Gap: Prime Minister's Report 2011, Commonwealth of Australia.

Australian Human Rights Commission (2011) Social Justice Report 2011, Australian Human Rights Commission.

Australian Human Rights Commission (2012) Aboriginal and Torres Strait Islander Peoples Engagement Toolkit 2012, Australian Human Rights Commission.

Australian Indigenous Doctors' Association and Centre for Health Equity Training (2010) Health Impact Assessment of the Northern Territory Emergency Response, Research and Evaluation, UNSW, Australian Indigenous Doctors' Association.

Australian Institute of Aboriginal and Torres Strait Islander Studies (2012), Guidelines for Ethical Research in Australian Indigenous Studies, 2nd edn, Australian Institute of Aboriginal and Torres Strait Islander Studies.

Australian Law Reform Commission (2011) Family Violence and Commonwealth Laws: Improving Legal Frameworks, Report No 117.

Australian National Audit Office (2012-2013) Administration of New Income Management in the Northern Territory, Audit Report No 19.

Tracey Banivanua Mar (2012) 'Settler-Colonial Landscapes and Narratives of Possession' 37/38 Arena Journal 176.

Larissa Behrendt (2001) 'Indigenous Self-Determination: Rethinking the Relationship Between Rights and Economic Development' 24 University of New South Wales Law Journal 850.

Larissa Behrendt (2003) Achieving Social Justice: Indigenous Rights and Australia's Future, Federation Press.

Larissa Behrendt (2007) 'The Emergency We Had to Have', in J Altman and M Hinkson (eds) Coercive Reconciliation, Arena Publications.

Richard Bellamy (2008) Citizenship: A Very Short Introduction, Oxford University Press.

Sol Bellear (2013) 'The Case for Indigenous Self-Determination', The Drum, Australian Broadcasting Corporation http://www.abc.net.au/news/2013-10-21/bellear-indigenous-sov ereignty/5032294, 21 October 2013.

Elizabeth Ben-Ishai (2012) Fostering Autonomy: A Theory of Citizenship, the State, and Social Service Delivery, Pennsylvania State University Press.

Shelley Bielefeld (2012) 'Compulsory Income Management and Indigenous Australians: Delivering Social Justice or Furthering Colonial Domination?' 35 University of New South Wales Law Journal 522.

Shelley Bielefeld (2013) 'Compulsory Income Management under the Stronger Futures Laws: Providing "Flexibility" or Overturning Freedom of Contract?' 8(5) Indigenous Law Bulletin 18.

Shelley Bielefeld (2014) 'History Wars and Stronger Futures Laws: A Stronger Future or Perpetuating Past Paternalism?' 39 Alternative Law Journal 15.

Peter Billings and Anthony Cassimatis (2010) 'Redesigning the Northern Territory Emergency Response: Social Welfare Reform and Non-Discrimination' 27(2) Law in Context 58.

Rob J Bray et al (2012) Evaluating New Income Management in the Northern Territory: First Evaluation Report, Social Policy Research Centre UNSW.

Morgan Brigg and Sarah Maddison (2011) 'Unsettling Governance: From Bark Petition to YouTube', in S Maddison and M Brigg (eds) Unsettling the Settler State: Creativity and Resistance in Indigenous Settler-State Governance, Federation Press.

Morgan Brigg and Lyndon Murphy (2011) 'Beyond Captives and Captors: Settler-Indigenous Governance for the 21st Century' in S Maddison and M Brigg (eds) Unsettling the Settler State: Creativity and Resistance in Indigenous Settler-State Governance, Federation Press.

Tom Calma (2007) 'Tackling Child Abuse and Inequality', in J Altman and M Hinkson (eds) Coercive Reconciliation, Arena Publications.

Ward Churchill (2011) 'A Travesty of a Mockery of a Sham: Colonialism as "SelfDetermination" in the UN Declaration on the Rights of Indigenous Peoples' 20 Griffith Law Review 526.

Commonwealth Ombudsman (2012) Review of Centrelink Income Management Decisions in the Northern Territory: Financial Vulnerability Exemption and Vulnerable Welfare Payment Recipient Decisions, Commonwealth of Australia. 
Christian Coons and Michael Weber (2013) Paternalism: Theory and Practice, Cambridge University Press.

Eva Cox (2011) 'Evidence-Free Policy Making? The Case of Income Management' 12 Journal of Indigenous Policy 1.

Department of Families, Housing, Community Services and Indigenous Affairs (2011) Stronger Futures in the Northern Territory Discussion Paper.

Patrick Dodson and Darryl Cronin (2011) 'An Australian Dialogue: Decolonising the Country', in S Maddison and M Brigg (eds) Unsettling the Settler State: Creativity and Resistance in Indigenous Settler-State Governance, Federation Press.

Gerald Dworkin (2013) 'Defining Paternalism', in C Coons and M Weber (eds) Paternalism: Theory and Practice, Cambridge University Press.

Equality Rights Alliance (2011) 'Women's Experience of Income Management in the Northern Territory' www.equalityrightsalliance.org.au, Accessed 23 November 2014.

Malcom Farr (2011) 'Tony Abbott Calls for Welfare Crackdown', News.com.au http://www. news.com.au/money/money-matters/quarantine-welfare-payments-to-essentials-says-opposition-leader-tony-abbott/story-e6frfmd9-1226031178877, 31 March 2011.

Paddy Gibson (2009) 'Return to the Ration Days: The NT Intervention: Grass-Roots Experience and Resistance', Jumbunna Indigenous House of Learning, University of Technology Sydney http://www.jumbunna.uts.edu.au/pdfs/JIHLBP11.pdf, Accessed 23 November 2014.

Paddy Gibson (2010) 'Business As Usual Under Labor's "New” Income Management', Crikey (online) http://www.crikey.com.au/2010/09/20/business-as-usual-under-labor $\%$ E2 $\% 80 \% 99$ snew-income-management, 20 September 2010.

David T Goldberg (2002) The Racial State, Blackwell Publishers.

Michele Harris (2013a) 'Sixth Anniversary of the Northern Territory Intervention: Striking the Wrong Note', Concerned Australians http://www.concernedaustralians.com.au/, Accessed 23 November 2014.

Michele Harris (2013b) In the Absence of Treaty, Concerned Australians.

David Hollinsworth (2006) Race and Racism in Australia, 3rd edn, Social Science Press.

Deirdre Howard-Wagner (2012) 'Reclaiming the Northern Territory as a Settler-Colonial Space' Arena Journal 220.

Human Rights and Equal Opportunity Commission (1997) Bringing Them home: Report of the National Inquiry into the Separation of Aboriginal and Torres Strait Islander Children From Their Families, Commonwealth of Australia.

Rosalind Kidd (1997) The Way We Civilise - Aboriginal Affairs - The Untold Story, University of Queensland Press.

Rosalind Kidd (2006) Trustees on Trial: Recovering the Stolen Wages, Aboriginal Studies Press.

Catriona Mackenzie (2008) 'Relational Autonomy, Normative Authority and Perfectionism' 39 Journal of Social Philosophy 512.

Sarah Maddison (2011) Beyond White Guilt: The Real Challenge for Black-White Relations in Australia, Allen \& Unwin.

Desmond Manderson (2012) 'Foreword: Social Injustice' 35(2) University of New South Wales Law Journal 408.

Michael Mansell (2007) 'The Political Vulnerability of the Unrepresented', in J Altman and M Hinkson (eds) Coercive Reconciliation, Arena Publications.

Bev Manton (2010) 'Perpetuating Neglect', Koori Mail, 11 August 2010, p 25.

Greg Marston et al (eds) (2010) Risk, Welfare and Work, Melbourne University Press.

Lawrence Mead (1997) 'The Rise of Paternalism', in L Mead (ed) The New Paternalism: Supervisory Approaches to Poverty, Brookings Institution Press.

Philip Mendes (2013) 'Compulsory Income Management: A Critical Examination of the Emergence of Conditional Welfare in Australia' 66(4) Australian Social Work 495.

Philip Mendes et al (2013) The Place-Based Income Management Trial in Shepparton: A Best Practice Model for Evaluation, Social Inclusion and Social Policy Research Unit, Department of Social Work, Monash University.

David Mercer (2003) “'Citizen Minus”: Indigenous Australians and the Citizenship Question' 7 Citizenship Studies 421. 
John Stuart Mill (1993 [1859]) On Liberty and Utilitarianism, Bantam Classic.

Gregory Mitchell (2004-2005) 'Libertarian Paternalism is an Oxymoron' 99 Northwestern University Law Review 1245.

Aileen Moreton-Robinson (2005) 'Patriarchal Whiteness, Self-Determination and Indigenous Women: The Invisibility of Structural Privilege and the Visibility of Oppression' in B Hocking (ed) Unfinished Constitutional Business? Rethinking Indigenous Self-determination, Aboriginal Studies Press.

Jeremy Moss (2010) 'Two Conceptions of Risk and Responsibility', in G Marston et al (eds) Risk, Welfare and Work, Melbourne University Press.

Steven Newcomb (2011) 'The UN Declaration on the Rights of Indigenous Peoples and the Paradigm of Domination' 20 Griffith Law Review 578.

Fiona Nicoll (2012) 'Bad Habits: Discourses of Addiction and the Racial Politics of Intervention' 21 Griffith Law Review 164.

Alastair Nicholson et al (2009) 'Will They Be Heard? A Response to the NTER Consultations June to August 2009' http://rollbacktheintervention.files.wordpress.com/ 2009/11/091123_will-they-be-heard.pdf, Accessed 21 November 2014.

Alastair Nicholson et al (2012) 'Listening But Not Hearing: A Response to the NTER Stronger Futures Consultations June to August 2011' http://www.jumbunna.uts.edu.au/ researchareas/ListeningButNotHearing8March2012.pdf, Accessed 23 November 2014.

Northern Territory Government (2007) 'Ampe Akelyernemane Meke Mekarle: "Little Children are Sacred": Report of the Northern Territory Board of Inquiry Into the Protection of Aboriginal Children from Sexual Abuse' http://www.inquirysaac.nt.gov.au, Accessed 21 November 2014.

Parliamentary Joint Committee on Human Rights (2013) 'Commonwealth Parliament, Examination of Legislation in Accordance with the Human Rights (Parliamentary Scrutiny) Act 2011: Stronger Futures in the Northern Territory Act 2012 and Related Legislation' http://www.aph.gov.au/Parliamentary_Business/Committees/Joint/Human_Rights/Completed_ inquiries/2013/112013/ /media/Committees/Senate/committee/humanrights_ctte/reports/2013/ 11_2013/pdf/c01.ashx, Accessed 25 November 2014.

JT Patton and W Ferguson (1999) 'Aborigines Claim Citizen Rights!' in B Attwood and A Markus (eds) The Struggle for Aboriginal Rights: A Documentary History, Allen \& Unwin.

Rollback the Intervention (2012) 'Submission No 40 to the Senate Standing Committee on Community Affairs, Parliament of Australia. Inquiry Into the Stronger Futures in the Northern Territory Bill 2011 and Two Related Bills' http://www.respectandlisten.org/ submission/stronger-futures.html, Accessed 23 November 2014.

Edward Said (1993) Culture and Imperialism, Vintage Books.

Danny Scoccia (2013) 'The Right to Autonomy and the Justification of Hard Paternalism' in $\mathrm{C}$ Coons and M Weber (eds) Paternalism: Theory and Practice, Cambridge University Press.

Senate Estimates (2014) Parliament of Australia, House of Representatives, Income Management Summary - 27 December 2013.

Barbara Shaw (2013) 'The NT Intervention: Six Years On', New Matilda https://newmatilda. com/2013/06/21/nt-intervention-six-years, 21 June 2013.

Barbara Shaw and Valerie Martin (2009) 'Talking up the Territory', speech delivered at Gnibi College of Indigenous Australian Peoples, Southern Cross University, 19 March.

Girardeau Spann (2000) 'Pure Politics' in R Delgado and J Stefancic (eds) Critical Race Theory: The Cutting Edge, 2nd edn, Temple University Press.

Guy Standing (2014a) A Precariat Charter: From Denizens to Citizens, Bloomsbury.

Guy Standing (2014b) The Precariat: The New Dangerous Class, Bloomsbury.

Cass Sunstein (2013) Simpler: The Future of Government, Simon \& Schuster.

Cass Sunstein and Richard Thaler (2003) 'Libertarian Paternalism is Not an Oxymoron' 70 University of Chicago Law Review 1159.

Tangentyere Council Incorporated (2012) 'Annual Report 2011/2012' http://www.tangentyere. org.au/publications/, Accessed 30 September 2014.

Richard Thaler and Cass Sunstein (2009) Nudge: Improving Decisions About Health, Wealth and Happiness, Penguin Books. 
Matthew Thomas and Luke Buckmaster (2010) 'Paternalism in Social Policy: When is it Hustifiable?' Research Paper No 8, Parliamentary Library, Parliament of Australia.

Sharon Venne (2011) 'The Road to the United Nations and Rights of Indigenous Peoples' 20 Griffith Law Review 557.

Alison Vivian (2010) 'The NTER Redesign Consultation Process: Not Very Special' 14 Australian Indigenous Law Review 46.

Irene Watson (1997) 'Indigenous Peoples' Law Ways: Survival Against the Colonial State' 8 Australian Feminist Law Journal 39.

Irene Watson (2007a) 'Aboriginal Women's Laws and Lives: How Might We Keep Growing the Law?' 26 Australian Feminist Law Journal 95.

Irene Watson (2007b) 'The Aboriginal State of Emergency Arrived with Cook and the First Fleet' 26 Australian Feminist Law Journal 3.

Irene Watson (2009) 'In the Northern Territory Intervention What is Saved or Rescued and at What Cost?' 15 Cultural Studies Review 45.

Irene Watson (2011) 'The 2007 Declaration on the Rights of Indigenous Peoples - Indigenous Survival - Where to From Here?' 20 Griffith Law Review 507.

Raelene Webb (2008) 'The Intervention: A Message From the Northern Territory' 7 Indigenous Law Bulletin 18.

Iris M Young (1990) Justice and the Politics of Difference, Princeton University Press. 